\title{
IAMJ
}

INTERNATIONAL

AYURVEDIC

MEDICAL JOURNAL

Research Article

ISSN: $2320-5091$

Impact Factor: 6.719

\section{A CLINICAL STUDY OF GUGGULU- SHIGRU KSHAR SUTRA IN BHAGANDARA (LOW LEVEL FISTULA)}

$\underline{\text { Shivam Shukla }}^{1}, \underline{\text { Pankaj Kumar Sharma }}^{2}$ Devesh Shukla $^{3}, \underline{\text { Rajeev Kumar }}^{4}$

${ }^{1}$ PG Scholar of PG Department of Shalya Tantra, Gurukul Campus, Uttarakhand Ayurved University, ${ }^{2}$ Professor \& H.O.D, PG Department of Shalya Tantra, Gurukul Campus, Uttarakhand Ayurved University, ${ }^{3}$ Associate Professor, PG Department of Shalya Tantra, Gurukul Campus, Uttarakhand Ayurved University, ${ }^{4}$ Assistant Professor, PG Department of Shalya Tantra, Gurukul Campus, Uttarakhand Ayurved University, Haridwar, Uttarakhand, India

Corresponding Author: hornbil0023@gmail.com

https://doi.org/10.46607/iamj0409052021

(Published Online: May 2021)

Open Access

(C) International Ayurvedic Medical Journal, India 2021

Article Received: 27/04/2021 - Peer Reviewed: 05/05/2021 - Accepted for Publication: 16/05/2021

\section{Check for updates}

\section{ABSTRACT}

Among all the notorious diseases Bhagandara is one such ano-rectal disease which have callous nature. The pain, inconvenience and constant discomfort hinder the natural routine of an individual and create problems for them. A revolutionary treatment approach to this disease is Kshar Sutra therapy. But it is the need of time to make more efficient Kshar Sutra by doing further research on them. Therefore, a research work was performed in Gurukul Campus of UTTARAKHAND AYURVED UNIVERSITY Haridwar, entitled 'A clinical study of Guggulu-Shigru Kshar Sutra in the management of Bhagandara (Low level fistula)'. It is a single blind controlled study where 30 patients who fit in the inclusion criteria were randomly selected for the study. The Guggulu-Shigru Kshar Sutra was used to treat their anal fistulas and was changed on $7^{\text {th }}$ day, $14^{\text {th }}$ day, $21^{\text {st }}$ day and so on till the end of the treatment. The present study has shown some very beneficial results in Unit Cutting Time (U.C.T.), pain, discharges, itching and burning sensation.

Keywords Bhagandara, Gurukul Campus, Low level fistula, Guggulu-Shigru Kshar Sutra, U.C.T., 


\section{INTRODUCTION}

Ayurveda is the oldest known traditional medical science which deals with the detailed aspects of human body from its normal functioning to the treatment of various disorders. Now a day a lot of research work had done in the field of Ayurveda to promote its standards. Shalya Tantra, which is one among Ashtang Ayurveda, got its origin from a divine soul Acharya Sushruta. Acharya Sushruta gave $4^{\text {th }}$ position to Bhagandara roga among the Astamahagadas ${ }^{1}$ (eight dreadful diseases) in his manuscript. Bhagandara is ancient disease which occurs in the ano-rectal region. Its classical feature is, firstly it occurs as Pidika around the Guda then it burst out and form Bhagandara. The modern correlation of Bhagandara is fistula-in-ano. Here fistula is the tract lined by granulation tissue which have one opening in the anal canal and other in the perianal skin. As Ayurveda has classified it as Astamahagada similarly in modern science this disorder is known for its high reoccurrence rate.

Fistulotomy and Fistulectomy are the two renowned surgical techniques for the treatment of anal fistula. But both these techniques have severe complications such as Incontinence due to sphincter muscle damage, rectal prolapse, fecal soiling, delayed healing of wound and subsequent high chance of reoccurrence. To overcome such complications Ayurveda is explored. Acharya Sushruta gave various treatment approaches for Bhagandara. One such technique is Kshar Sutra ${ }^{2}$ which was later elaborated by Acharya Chakradutta. Acharya Chakradutta explained the methods of its preparation and its application over the Bhagandara patients. From a long period of time Kshar Sutra proven as the boon for the treatment of anal fistula. The principle of Kshar Sutra is to maintain adequate drainage of the tract as well excise the tract gradually. The Kshar Sutra dissolve the tough fibrous tissue and drains the pus thus facilitates the granulation tissue formation to heal.

\section{Need of Study}

Nobody can deny the fact that traditionally used Kshar Sutra is a boon for Ayurvedic surgeons for treating fistula patients. But certain inconveniences were observed during Kshar Sutra therapy and they are worth noting. The limited availability of Apamarga plant and highly irritant characteristic of Snuhi ksheer makes this Kshar Sutra discomfort for patient. Also, it has been seen that Apamarga Kshar Sutra causes pain, burning sensation, inflammation and other discomforts to the patients. The Apamarga plant is only available in rainy season. All these factors collectively make it feel a need of new Kshar plant which is perineal and having less adverse effects without compromising the efficacy of Kshar. Therefore, in this study a new Kshar plant is taken into consideration i.e. Shigru and to lessen the complications caused by Snuhi, Guggulu extract is used.

\section{Aim and Objectives}

Preparation of Guggulu based Shigru Kshar Sutra

1. To evaluate the efficacy of Guggulu-Shigru KsharSutra Therapy in Bhagandara (Low Level Fistula).

2. To evaluate the intensity of pain, burning sensation and itching, so that the patient can do his routine works comfortably.

3. To find the recurrence, if any, during the study period.

4. To enhance the rate of healing.

\section{Materials and Methods}

The present study was based on the clinical findings gathered during the study and it was randomized controlled trial.

Selection of Patients: A count of 30 patients were selected and carefully examined from the OPD/IPD of Gurukul Campus of Uttarakhand Ayurved University, Haridwar. The informed written consent were taken from them prior to the initiation of research work. The examination of the patients is carried out with the help of proforma and findings were recorded in it.

The Ethical clearance number is Uttarakhand Ayurved University/GC/IEC/2020/4.

Method of Kshar Sutra Therapy

- Pre-operative preparation

- Operative procedure Kshar Sutra ligation under suitable Anesthesia

- Post-operative measures

- Kshar Sutra Changing on $7^{\text {th }}, 14^{\text {th }} 21^{\text {st }} \& 28^{\text {th }}$ days of follow up. 


\section{Inclusion criteria}

- The patients having sign and symptoms of Bhagandara (low level anal fistula), were selected for present study.

- The patients of the age group 16-60 years were selected.

- Fresh as well recurrent cases were also registered for the research purpose.

\section{Exclusion criteria}

- HIV, HCV and HbSAg positive patients.

- Secondary fistula due to -

- Ulcerative colitis

- Crohn's disease

- Tuberculosis

- Carcinoma of rectum

- High level Fistula

- Piles, Fissure and any other ano-rectal disorder
- Others

All the 30 patients of Bhagandara were treated with Guggulu based Shigru Kshar Sutra.

\section{Selection of Drug}

The Shigru plant is used as a medicinal herb from a long period of time. Shigru poses Kapha-Vaat Shamak properties therefore it acts as anti-inflammatory and analgesic agent. The paste of the bark is used for healing wounds. The oil of Shigru seed were used in Osteo-arthritis. This plant is mentioned in Kshar Dashak by Raj Nighantu. But its Kshar efficacy is not being tested yet. Therefore, after going through from the previous research work done on the Bhagandara we decided to perform a research work on Shigru Kshar to give an alternative perennial plant for the Kshar formation instead of the seasonal plant (Apamarga).

In this study the Bark of Shigru plant is used for Kshar formation.

\section{Investigations}

Table 1: The blood and other radiological investigations were done as per requirements:

\begin{tabular}{|l|l|l|}
\hline S. No & A. Laboratory investigations \\
\hline 1. & Blood Investigations & $\begin{array}{l}\text { Complete haemogram which includes Hb \%, TLC, DLC, ESR, BT, CT, } \\
\text { B. Sugar- fasting and pp, LFT, KFT, HIV, HbsAg, HCV, Any other (if required) }\end{array}$ \\
\hline 2. & Urine & Routine and Microscopic (if required) \\
\hline 3. & Pus & Culture and Sensitivity (if necessary) \\
\hline 4. & Stool & Ova, cyst \& pus cells (if required) \\
\hline B. Proctoscopy
\end{tabular}

\section{Adjuvant Therapy}

Avagaah sveda with Sphatik bhasma were instructed to the patients twice daily. In morning it was advised just after defecation and in second time in evening. The duration of avagaah sveda was 15 minutes.

Guggulu preparation (Triphala Guggulu ${ }^{5}$ ) was used as an internal medication, it had proven successful in preventing the secondary infections.

Matra basti of Jatyadi tail ${ }^{6}$ keeps the anal canal lubricated, reduces inflammation and prevents secondary infections.

Stool softener is also given to patients which was advised at bedtime so that there will not be pain by pulling of Kshar Sutra while defecating.

\section{Period of Study}

The treatment was variable because of the different length of fistulous tract in different patients. However, patients were instructed to have a weekly visit for changing Kshar Sutra. The changing Kshar Sutra is done till the complete cut through of the fistulous tract and gradual tightening of Kshar Sutra was also done. After completion of the study the patient is followed up for 3 months at the interval of 15 days.

\section{Assessment Criteria}

Subjective criteria

1. Kandu (Itching): (Mild, Moderate, severe, \& very severe)

2. Ruja (Pain): (Mild, Moderate, severe, \& very severe) 
3. Srava (Discharge): (Mild, Moderate, severe, \& very severe)
4. Daha (Burning sensation): (Mild, Moderate, severe, $\&$ very severe)

\section{Objective criteria}

Total No. of days taken for cut through

U.C.T. $=$ Initial length of track in $\mathrm{cms}$

$=$. .Days $/ \mathrm{cm}$

Initial length of track in cms

Table 2: Parameters for Assessment of Burning Sensation $\rightarrow$

\begin{tabular}{|l|l|}
\hline Explanation & Grade \\
\hline No complaint & 0 \\
\hline Negligible feeling of burning sensation for few minutes in a day & 1 \\
\hline Tolerable burning sensation completely relived by hot sitz bath or local application of Oil & 2 \\
\hline $\begin{array}{l}\text { Tolerable but constant burning sensation slightly relived by hot sitz bath or local application of } \\
\text { Oil }\end{array}$ & 3 \\
\hline Unbearable burning sensation which makes the patient to seek medical help as soon as possible. & 4 \\
\hline
\end{tabular}

Table 3: Parameters for Itching Assessment $\rightarrow$

\begin{tabular}{|l|l|}
\hline Explanation & Grade \\
\hline No complaint & 0 \\
\hline Negligible Itching for few minutes in a day & 1 \\
\hline Occasional sensation of itching with 4-6 hrs interval & 2 \\
\hline Frequent sensation itching with 2-3 hrs interval & 3 \\
\hline Continuous sensation of itching with 15-30 min interval & 4 \\
\hline
\end{tabular}

Table 4: Parameter for assessment of discharge $\rightarrow$

\begin{tabular}{|l|l|}
\hline Explanation & Grade \\
\hline No sign of any discharge & 0 \\
\hline Occasional appearance of discharge and patient and use single cotton pad in $24 \mathrm{hrs}$ & 1 \\
\hline Frequent appearance of discharge and patient use 3-4 cotton pad in $24 \mathrm{hrs}$ & 2 \\
\hline Increased frequency of discharge and patient use 5-6 cotton pads in $24 \mathrm{hrs}$ & 3 \\
\hline Continuous discharge & 4 \\
\hline
\end{tabular}

Table 5: Parameters for Pain Assessment $\rightarrow$

\begin{tabular}{|l|l|}
\hline Explanation & Grade \\
\hline No complaint of pain & 0 \\
\hline Negligible/tolerable pain. & $1-3$ \\
\hline Localized tolerable pain completely relived by hot sitz bath & $4-6$ \\
\hline Intolerable pain, not relieved by hot sitz bath relived by oral analgesic, no disturbance in sleep & $7-8$ \\
\hline Continuous and intolerable pain with sleep disturbance. Patient seek medical help as early as possible. & $9-10$ \\
\hline
\end{tabular}




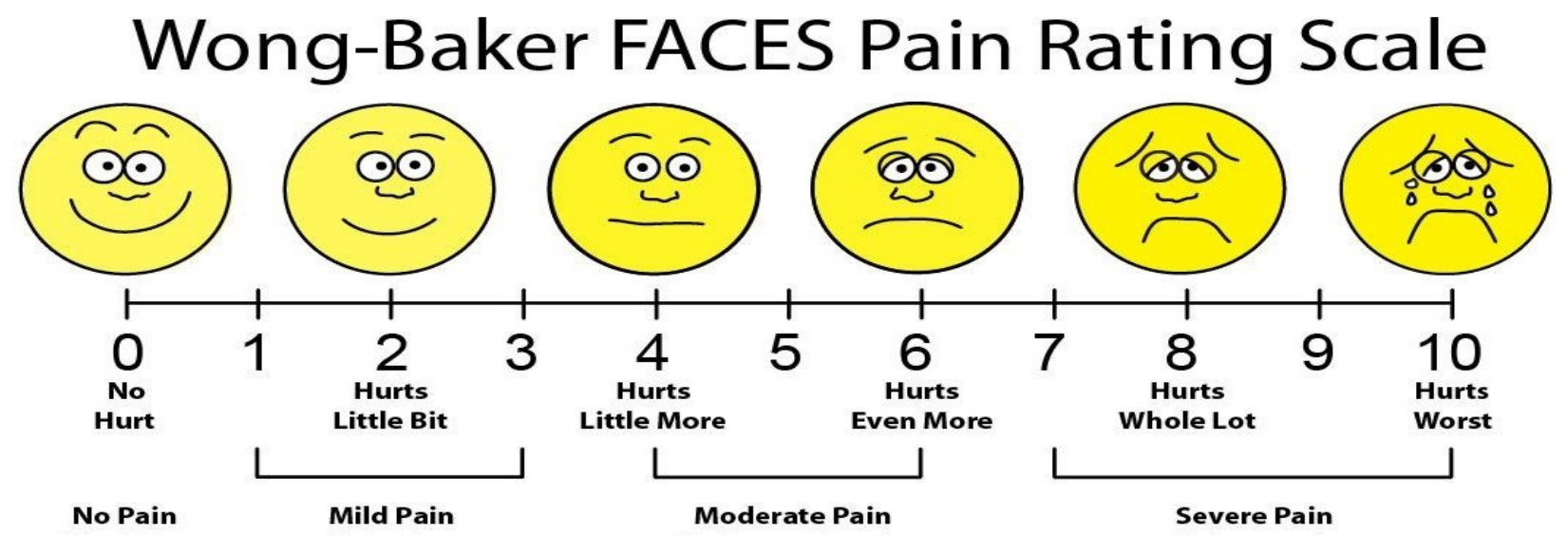

Table 6: Efficacy of Kshar Sutra Therapy

\begin{tabular}{|l|l|l|}
\hline \multicolumn{2}{|c|}{ Efficacy of Kshar Sutra Therapy } \\
\hline S. No. & Observation & Percentage \\
\hline 1. & No relief & $0 \%$ \\
\hline 2. & Mild relief & $1-25 \%$ \\
\hline 3. & Moderate relief & $26-50 \%$ \\
\hline 4. & Significant relief & $51-75 \%$ \\
\hline 5. & Excellent relief & $76-100 \%$ \\
\hline
\end{tabular}

\section{Statistical Analysis}

The data which was collected form the above-mentioned parameters were statistically analyzed with the help of mean (X), standard deviation (S.D.), standard error (S.E.), parametric and non-parametric tests.

\section{Observations and Results}

Table 7: \% age relief

\begin{tabular}{|l|l|}
\hline Subjective Parameters & \% relief \\
\hline Ruja (Pain) & $88.8 \%$ \\
\hline Daha (Burning Sensation) & $78.21 \%$ \\
\hline Srava (Discharges) & $91.34 \%$ \\
\hline Kandu (Itching) & $83.15 \%$ \\
\hline Objective Parameters & \\
\hline Unit Cutting Time & $7.011 \mathrm{day} / \mathrm{cm}$ \\
\hline
\end{tabular}

Demographic Observation made during the study are as follows:

Table 8: Total number of patients

\begin{tabular}{|l|l|l} 
Registered & Discontinued & Completed \\
\hline 30 & 0 & 30
\end{tabular}




\section{Koshtha Lakshana wise detailing of Patients:}

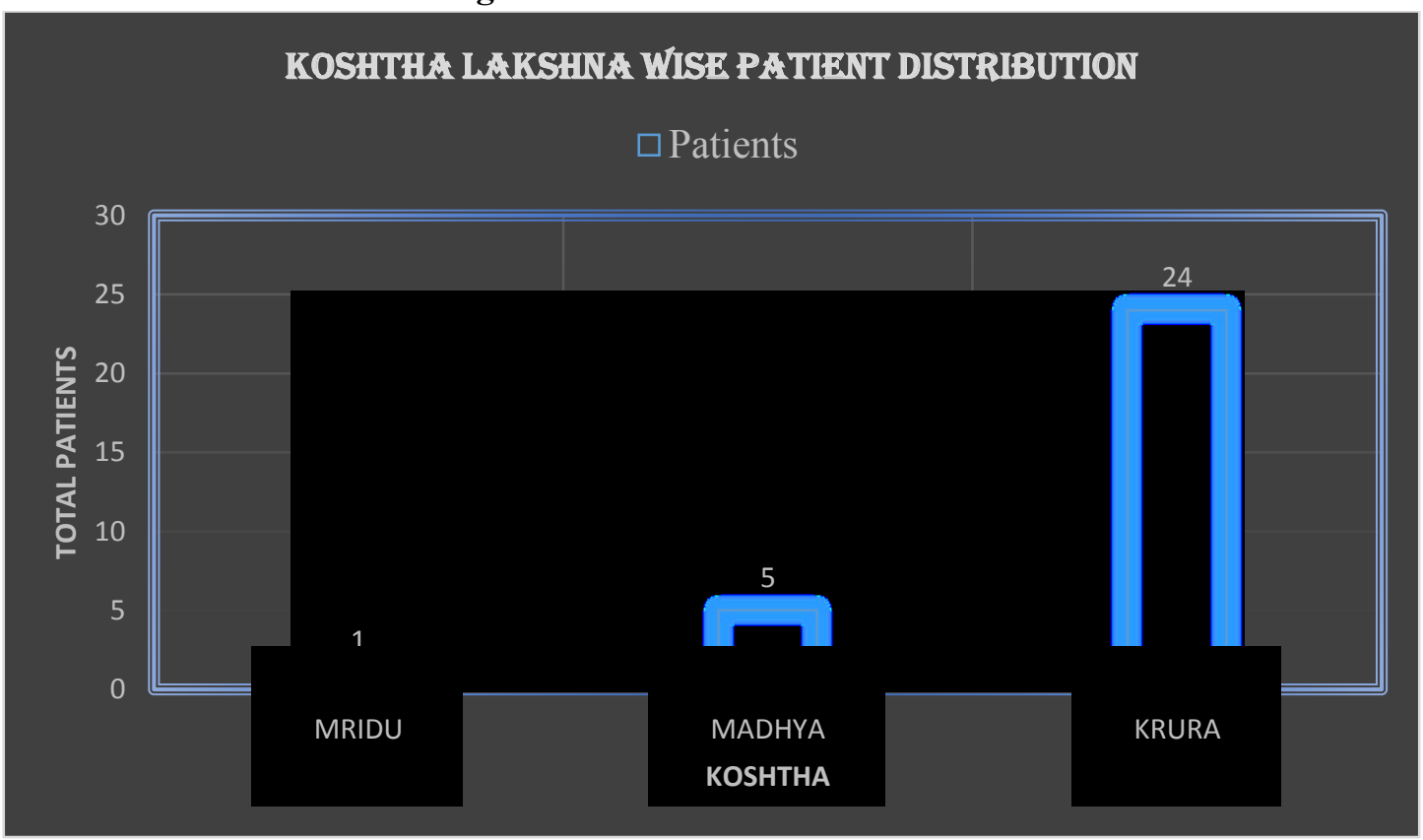

Table 9: Patients distribution according to their Koshtha

\begin{tabular}{|l|l|l|l|}
\hline Koshtha & Number of Patients & Total patients & Percentage (\%) \\
\hline Mridu & 1 & \multirow{2}{*}{30} & $3.3 \%$ \\
\hline Madhya & 5 & & $16.6 \%$ \\
\hline Krura & 24 & & $80 \%$ \\
\hline
\end{tabular}

2. Type of Bhangadara wise patients:

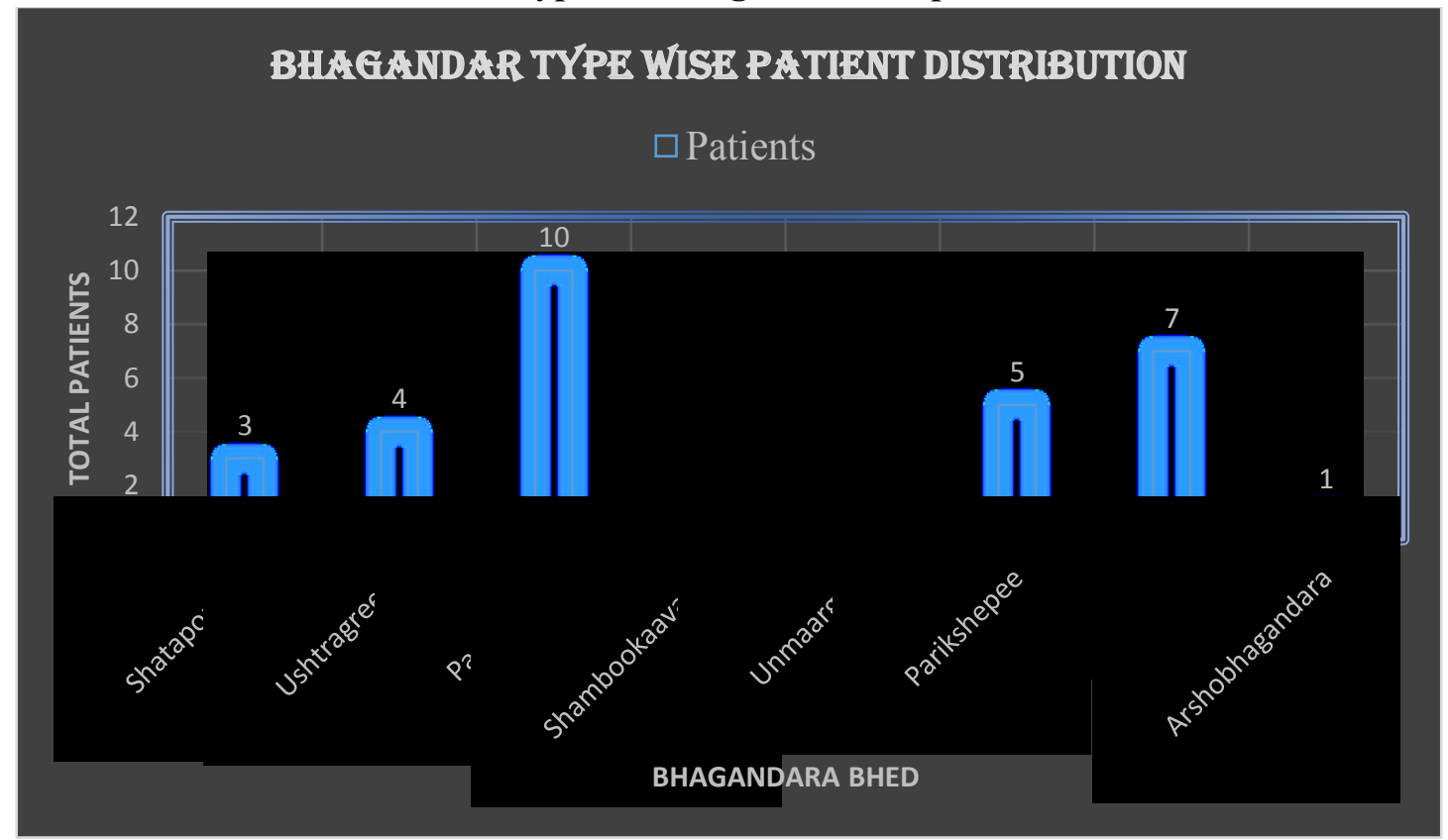


Table 10: Patients distribution according to the Bhagandara Bheda

\begin{tabular}{|c|c|c|c|}
\hline Type of Bhangadara & Number of Patients & Total Patients & Percentage $(\%)$ \\
\hline Shataponaka (Vaataja) & 3 & \multirow{8}{*}{30} & $10 \%$ \\
\hline Ushtragreeva (Pittaja) & 4 & & $13.3 \%$ \\
\hline Parisraavee (Kaphaja) & 10 & & $33.3 \%$ \\
\hline Shambookaavarta (Sannipaataja) & 0 & & 0 \\
\hline Unmaargee (Aagantuja) & 0 & & 0 \\
\hline Parikshepee (Vaatapittaja) & 5 & & $16.7 \%$ \\
\hline Riju (Vaatakaphaja) & 7 & & $23.3 \%$ \\
\hline Arshobhagandara (Kaphapittaja) & 1 & & $3.3 \%$ \\
\hline
\end{tabular}

3. Type of fistula in ano wise patient distribution:

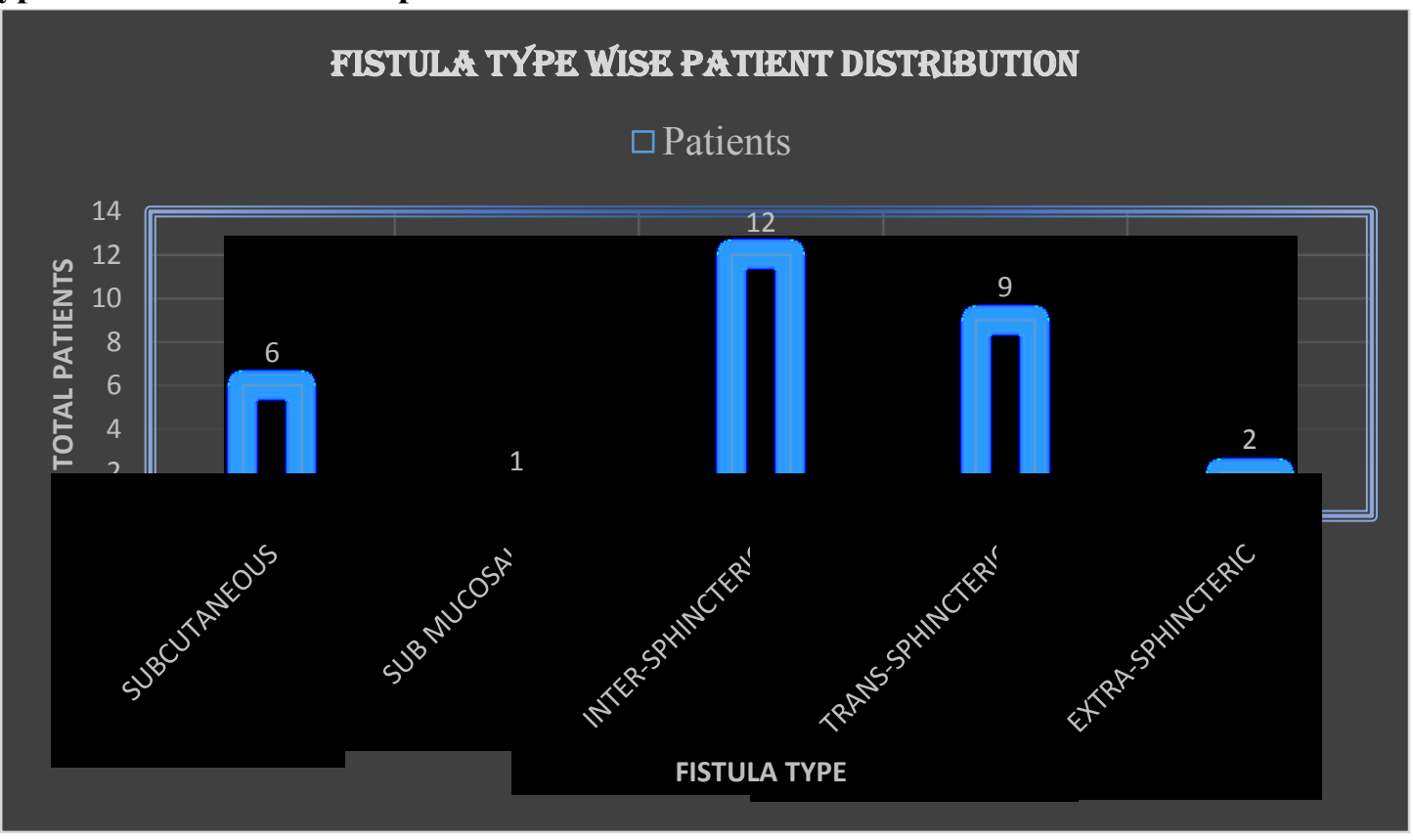

Table 11: Patients distribution according to the type of fistula

\begin{tabular}{|l|l|l|l|}
\hline Type of fistula & Number of Patients & Total Patients & Percentage (\%) \\
\hline Subcutaneous & 6 & & $20 \%$ \\
\hline Sub mucosal & 1 & \multirow{3}{*}{30} & $3.3 \%$ \\
\hline Inter-sphincteric & 12 & & $40 \%$ \\
\hline Trans-sphincteric & 9 & & $30 \%$ \\
\hline Extra-sphincteric & 2 & & $6.67 \%$ \\
\hline
\end{tabular}

\section{DISCUSSION}

The results were obtained from the assessment criteria which was recorded before and after treatment.

Ruja (Pain): It was observed that after the completion of the therapy the pain management was $88.8 \%$. This reveals that Guggulu-Shigru Kshar Sutra have a good therapeutic effect in pain management while excising the fistulous tract. This effect of Shigru Kshar is due to the Vata Shamak property of Shigru plant. This property makes it act as an anti-inflammatory and analgesic agent.

Kandu (Itching): It was observed that after the completion of the therapy the Itching was relieved about $83.15 \%$. According to Ayurvedic text the Kapha Dosha 
is mainly responsible for Kandu (itching) and Shigru have Kapha Doshaghna property in it. Thus, the relief over the itching was also seen in maximum number of patients.

Daha (Burning Sensation): It was observed that after the completion of the therapy the burning sensation was relieved about $78.21 \%$. Burning sensation is less in comparison to the traditionally used Kshar Sutra. As in this Kshar Sutra we have replaced irritant Snuhi with Guggulu extract as a binding agent. Also, Guggulu poses some properties like Krimighna ${ }^{7}$ analgesic and anti-inflammatory, which make it more suitable choice over the Snuhi. Also, the Kapha-Vatahara property of Shigru lessen the sufferings of patients.

Srava (Discharges): The srava was last parameter of this study and statistically it had also shown marked improvement which is about $91.34 \%$. This was possible due to Krimighna property of both Shigru and Guggulu. Krimighna property of Kshar Sutra lessens the pus discharge and also inhibits the growth of secondary infectious agents. Also, Shigru have vrana shodhana property which debrides the necrosed tissue of fistulous tract and promotes the healthy granulation tissue formation.

Unit Cutting Time (U.C.T): Unit cutting time was an important objective parameter of this study which decide whether the patient got cured or not. The average U.C.T. of Guggulu-Shigru Kshar Sutra comes out 7.01 days $/ \mathrm{cm}$. This U.C.T. is a good rate of excising fistulous tract with minimal sufferings of the patients.

\section{CONCLUSION}

The observations and results obtained from the study justifies that Guggulu based Shigru Kshar Sutra is a better alternative approach of traditional Kshar Sutra due to more acceptability, easily available and better wound healing property after cutting through of fistula. From the above discussion it can be concluded that Guggulu-Shigru Kshar Sutra is effective in both excising the fistulous tract and decreasing the suffering of the patients.

\section{REFERENCES}

1. Sushruta Samhitaa with Aayurveda Tatva Sandeepika commentary by Dr Ambikaa Datta Shaastry, Chaukhambhaa Sanskrita Sansthaana, VaaraaNaasi, reprint edition- 2018 Sootra Sthana 33 / 4, page no.163.

2. Sushruta Samhitaa with Aayurveda Tatva Sandeepika commentary by Dr Ambikaa Datta Shaastry, Chaukhambhaa Sanskrita Sansthaana, VaaraaNaasi, reprint edition- 2018 Chikitsa Sthana 17 / 30-32, page no.101.

3. Dravyaguna vigyan vol 2 Chaukhamba Bharati Academy, Varanasi edition 2017 Page no. 111-114.

4. RAJ-NIGHANTU Mishrak varag First edition 2012page no. 1077-1078.

5. Bhaisajya Ratnavali, 47/49. In. Govind das sen K, editor. Varanasi: Chaukhambha surbharati prakashan; 2011, p. 824.

6. Bhaisajya Ratnavali, 61/139-142. In. Govind das sen K, editor. Varanasi: Chaukhambha surbharati prakashan; 2011, p. 965.

7. Dravyaguna vigyan vol 2 Chaukhamba Bharati Academy, Varanasi edition 2017 Page no. 54-58

\section{Source of Support: Nil \\ Conflict of Interest: None Declared}

How to cite this URL: Shivam Shukla et al: A Clinical Study Of Guggulu- Shigru Kshar Sutra In Bhagandara (Low Level Fistula). International Ayurvedic Medical Journal \{online\} 2021 \{cited May, 2021\} Available from: http://www.iamj.in/posts/images/upload/967 974.pdf 